УДК: 81:929 Белић А.

81:929 Белић А.(082)(049.32)

DOI: https://doi.org/10.18485/belic_slv.2017.2.ch6

Радоје Симић

\title{
САРАДЊА ФИЛОЛОГА ИЗ ЈУГОСЛОВЕНСКИХ ЦЕНТАРА ВАН БЕОГРАДА У БЕЛИЋЕВИМ И „БЕЛИТЕВСКИМ” \\ ЕДИЦИЈАМА
}

\begin{abstract}
1. Увод
1. Александар Белић је, по општој оцени, прави оснивач и централна личност свеколике српске науке о језику. Родио се (Београд 1876) у доба наглог успона ове области људске духовне делатности, када је интересовање за генезу и еволуцију људске расе привлачило пажњу највећих светских умова (то је време историјско-компаративних и младограматичарских открића у лингвистици), и доживео златно доба тих наука у време структурализма. То је и време здравих политичких погледа на национално питање југословенских народа, време њихова успона и напретка узајамности међу њима, ослобођења од туђинских власти и стварања југословенске државе. Имао је среће да оде са овог света пре него што је почео процес политичког разлаза који је донео крвав рат и неславно финале са несагледивим последицама по будућност сваког од тих народа понаособ, који као да таворе своје последње дане у политичком беспућу, економском безнађу и катастрофалном демографском назатку. Имао је и среће да не доживи невиђену кризу и методолошки колапс језичких истраживања, која управо од његове смрти полако одумиру на теоријским странпутицама, а у општој истраживачкој неодговорности.

2. Колико је дијапазон Белићевих научних интересовања за језичка питања био широк, а резултати вредни сваког поштовања ${ }^{1},-$ исто је тако широк круг људи с врхова тадашње светске лингвистике с којима је Белић сарађивао, и који су с њим на различите начине сарађивали. Међу
\end{abstract}

1 Исп. Белић 1998-2000, где се на пар хиљада страница више него јасно огледају све јаке стране Белићевог научног стваралаштва. 
њима су и таква имена као руски великани Р. Јакобсон, Н. С. Трубецки, С. Карцевски, С. Б. Бернштајн, Н. И. Толстој, француски корифеји А. Вајан, А. Меје, А. Мазон, онда чувени Л. Хјелмслев, М. Фасмер, В. Брендал, Б. де Куртене, Н. ван Вејк, Ј. ван Гинекен, П. Дилс, Н. Јокл, Ј. Ј. Микола, Т. Милевски, М. Малецки и многи други².

3. Наша је намера да представимо неке детаље о Белићевим сарадницима са простора бивше Југославије који не припадају најужем београдском кругу. То су његове колеге из Хрватске, Словеније, Босне и Херцеговине, Црне Горе и Македоније, касније, кад је основан Новосадски универзитет и Филозофски факултет - и из Новог Сада. Грађу смо прикупили из три зборника у част А. Белића, и из 'Јужнословенског филолога' у време док је он био уредник (од оснивања 1913, до 1960). Највише је сарадника у разним издањима из Хрватске, што је и нормално с обзиром на опште и научне потенцијале хрватског народа, сразмерно су чести прилози из Словеније, док из Босне и Херцеговине (Ј. Вуковић), Црне Горе и Македоније има врло мало.

4. Покушали смо представити све што је на поменутим страницама објављено са тих страна и да местимично дамо и сопствени суд. Но опште закључке о сарадницима, сарадњи, радовима и њиховом квалитету и значају, те о приликама у којима се она одвијала, као и о кретању те сарадње током времена, укратко смо формулисали у закључним напоменама.

\section{2. Зборници посвећени Белићу}

1. Изгледа да је најоправданије приказати грађу по едицијама у којима се налази објављена. Зато смо одлучили и груписати је по том принципу. Дакле, најпре ћемо прегледати три зборника објављена у Белићеву част.

2. Први од тих зборника издали су 1921. године „пријатељи и ученици” Белићеви. Интересантно је да се међу њима нашао и Белићев учитељ Љ. Стојановић, који је у улози уредника написао и необичан предговор. Обраћајући се директно Белићу речима „Драги учениче и учитељу!” Стојановић скромно и искрено одаје признање већ тада у међународним размерама познатом и признатом Белићу. - Пише и следеће: „Ти си већ досад повукао дубоку бразду у науци о језику, која те истакла међу прве

2 Углавном су то имена сарадника у зборницима посвећеним А. Белићу, где нпр. нема В. В. Виноградова, Б. Хавранека и многих других с којима је Белић одржавао повремено чак и присне везе. 
раднике у тој струци. То признају сви који се баве словенском филологијом, и који се у својим студијама без твојих радова не могу обићи...”. Закључак Стојановићев још је необичнији: „Ја лично нарочито сам пун радости, што те у име њихово и своје поздрављам, јер као год што сваки отац жели и радостан је кад му је син бољи од њега, тако сам и ја радостан што сам дочекао да мој ученик буде бољи од учитеља, па и теби желим да дочекаш ту радост, и да одгајиш ученике које ћеш под старост овако поздрављати као ја тебе данас". Белић је међутим израстао у такву научну величину с којом се ретко ко може поредити не само у домаћој српској науци о језику него и у европским и светским размерама.

Но ми ћемо оставити ту тему и приступити приказу радова оних научних радника који су радили ван Београда, дакле у другим југословенским научним и универзитетским центрима, а чији су радови објављени у првом поменутом зборнику.

Фр. Рамовш (1: 17-23), Opazke k nenaglašenemu ê s posebnim ozirom na praslovensko ${ }^{*} \hat{s} t e \hat{j} a v$ slovenskih narečjih - за предмет има детаље из развоја словенског и словеначког вокализма у вези са акценатским променама.

Р. Нахтигал (1: 87-96), Oblikepo osnovah na-u-vstarocerkevnoslovanskih spomenikih, упозорава најпре на судбину у-основа, тј. на њихово изједначавање са о-основама, у већини словенских језика. Затим утврђује њихову релативно живу употребу у старословенским споменицима. „Pri tem vidimo še časovno in dialektično razliko v starocerkevnoslovanskih spomenikih".

М. Будимир (1: 97-112), Ievr. *kleu- 'teći, plaviti, prati, čistiti', са широких лингвистичких и класичнолингвистичких позиција тумачи заправо

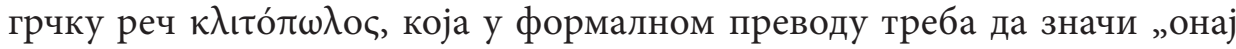
који има славну ждребад”. Али дубљим истраживањима аутор долази до закључка „да овде $\pi \omega \lambda$ оц значи и 'равница', а не само 'ждребе'. Даље развијајући ове мисли, Б. долази и до других, далекосежнијих уверења о развоју класичног грчког лексичког система.

П. Скок (1: 119-128), Studije iz srpskohrvatske toponomastike, води расправу о неколико имена места (Бањевац = Бања Вас; Башћица „Ријеч је према томе, изузевши суфикс, тамна”; те Билице, Бокањац, Брисник итд.). Уложивши своју изванредну класичну и словенску филолошку спрему, Скок се већ у овом раду издваја својом високом способношћу у расправљању сложених етимолошких и ономастичких питања.

Фр. Фанцев (1: 174-179), Marko Andriolić, zaboravljeni pisac 16. vijeka, износи основне податке о Андриолићу сачуване у поменима о њему.

Х. Барић (1: 185-195), Guturalni problemi (Jermenski refleksi ievr. nepalatalnih guturala), даје повода само да се с дивљењем присетимо ко- 
лико су раније генерације професора ишле у ширину и дубину филолошких знања. Иначе нисмо у стању оценити расправу о предмету о којем немамо ни најминималнијих знања. Аутор наиме пореди најпре албански са јерменским, да би у расправи која следи, и у којој се аутор дотиче индоевропског прајезика, келтских језика итд. водио ка закључку о очувању индоевропског стања у питању неких гутурала.

Фр. Илешић (1: 233-238), Slovensko pismo u jednoj talijanskoj knjizi 16. stoleća, кратко извештава о теми, са илустрацијама које показују глагољска и ћириличка слова. При томе исправља Миклошићеве тврдње да су ове табеле послужиле као узор Бохоричу за његов приказ словенских писама.

3. Други зборник у Белићеву част издат је 1937, „о четрдесетогодишњици његова научног рада". Белићева библиографија, која претходи радовима на почетку зборника, износи већ тада укупно 316 јединица, у распону од савременога српског језика и његове унутрашње и вањске историје и теорије, преко словенске упоредне граматике и индоевропеистике, до општелингвистичких питања која су се у то време постављала и решавала у светској науци. Разгледаћемо укратко радове југословенских филолога, линвгиста и научника сродних оријентација који су живели и радили ван Београда.

M. Решетар (2: 1-7), Odakle je Gundulić prevodio svoje 'Pjesni pokorne', трага за изворима и узорима великог дубровачког песника, и као и његови претходници у овоме послу, колеба се између латинске Вулгате и црквенословенских преводних варијаната Давидових псалама.

П. Скок (2: 21-30), Iz srpskohrvatske onomastike. Tip 'Blagaj', објашњава дати топоним полазећи од значења суфикса -(j)aj, који сматра заправо двојаким. Један од њих служи за творбу апстрактних именица од глаголских основа (исп. промашај, загрљај), а други од придева. Благај припада другој групи изведеница. Узгред напомиње да је топоним Космај настао „од прастарог адјектива kosmъ (адјективна изведеница од коса)...”.

О. Колман (2: 47-54), Једна досада необјавъена песма Џоре Држића, упозорава најпре на грешке и нетачности у дотадашњим издањима Држићевих песама (нпр. „Уопште, нека нам се не замери ако, на основу проучавања Јагићевих извора за текст Држићевих песама, изјавимо да је његов критички апарат често врло некритичан и непоуздан”), па затим обавља реконструкцију једне непотпуно и нетачно објављене песме.

J. Гривец (2: 135-140), Prvo poglavje Žitja Metodija, расправља о теолошком смислу датог текста, и његовим преводним тумачењима.

Ђ. Шкарић (2: 141-146), Прилог за српскохрв. етимологију, боље би било рећи прилози, објашњава речи гобеља („наплатак у кола”), говјети 
(„угађати”), увотка/ухотка (јарица или овчица „у трећој години”) и штурица („јуница која је већ у другој мјесто у трећој години”), и упућује на крајеве где се употребљавају.

M. Храсте (2: 147-154), Osobine govora ostrva Visa, укратко описује основне црте (гласови, акценат, облици) отока Виса, и у прилогу даје кратке примере говорне речи. Говор је чакавски, са цакавском варијацијом дела отока. Аутор уз то напомиње да је Вис административно од најстаријих времена чинио јединствену целину са Хваром, као део заједничке територије. Том одговарају и говорне особине њихове: „Višani govore istim dijalektom kao i Hvarani, pa dijalekti tih dvaju ostrva čine jednu dijalekatsku celinu. No ima i nekih razlika između njih...."

Стј. Ившић (2: 183-195), Osnovna hrvatska kajkavska akcentuacija u Pergošića (1574), утврђује да је М. Пергошић писао „стилизираним” језиком који се не поклапа ни са једним кајкавским говорним типом, али његова грађа потврђује да се „današnja osnovna hrvatska kajkavska akcentuacija gotovo potpuno potvrđuje primjerima od prije tri i po vijeka”.

М. Мурко (2: 225-239), Glagol knaditi (Prilog leksikografiji i proučavanju narodne epike), утврђује најпре да „реsme nije stvorio mističan 'narod pevač' (nemački: das singende Volk), kako su mislili nemački (osobito Jakob Grimm) i slovenski romantičari, nego daroviti pojedinci, dakle umetnici u narodu, čija su imena doduše obično nepoznata". Што се тиче речи о којој Мурко пише, она је потврђена у Херцеговини, где певачи умеју „sknaditi pjesmu o svakijem, izmisliti ako i nije bilo" догађаја и личности о којима се прича. Етимологију ове речи аутор оставља „balkanolozima da joj nađu izvor”.

Ј. Вуковић (2: 231-232), Питате глаголског вида облика 'будем': „Наше језичко осећање анализом, извршеном на свим облицима, показаће нам да је бити као самостални глагол увек несвршен и у облицима од основе буд".

Вл. Ћоровић (2: 233-234), Откуда име Врчин?, указујући на постојање латинског натписа на плочи нађеној у зони Авале, на којој се спомиње „Deae Orciae sacrum”, аутор мисли да је култ локалне богиње Орције послужио као изворни облик за настанак топонима Врчин (пореди са „hortus - ortus - врm; orceus - urceus - врч”.

Ср. Живковић (2: 297-305), Još dve teorije o postanku jezika, приказује неке глотогенетичке идеје које нису ушле у његову 'Опћу лингвистику'. Једна од тих теорија (Е. Böklen, Die Entstehung der Sprache im Lichte des Mytos) религијска је по основном смислу јер је моногенетска и настанак језика објашњава вербализацијом сакралних ритуала. Друга (L. Kürcz, Der naturlautliche Ursprung der Sprache und Schrift), корене језика налази у имитацији природних звукова. Трећа теорија (H. Ammann, Vom 
Ursprung der Sprache) настанак језика тумачи појавом разума код људске врсте: „Pоmоću razuma nastaju od signala rečenice, od glasovnih gesta reči; a u tome je prelaz od predjezičkog stanja u jezičko. Duševni život je ono podzemlje u kome se krije jezička reka, iz koga ona izvire".

Фр. Рамовш (2: 339-346), K razvoju $\mathrm{s}$ in $\boldsymbol{z} v$ slovenskem jeziku, утврђује у крајњој линији да су рефлекси двају полугласника у словеначким дијалектима разноврсни, али да сви имају базну вредност вокала е или ә.

Ст. Шкерљ (2: 417-429), Безличне повратне реченице са активном конструкиијом, за предмет свога рада има реченице типа Obesilo se ga je у словеначком језику.

4. Трећи „Зборник радова о Александру Белићу”, са исцрпном библиографијом Белићевих радова (укупно 691 библ. јединица), из штампе је изашао 1976, поводом стогодишњице Белићева рођења, а у редакцији М. Стевановића, Р. Бошковића и П. Ивића, несумњиво Белићевих најистакнутијих ученика. Уредник је М. Стевановић.

На челу зборника, чинећи част у подухвату око уређивања зборника, и самом великом Белићу, а и науци којом се са огромним успехом бавио, стоје речи академика Павла Савића, Белићевог савременика и сарадника у часном послу око организације и руковођења научним пословима САНУ: „Ове године - тако почиње Савићев осврт на Белићев рад - навршава се сто година од рођења Александра Белића, научника светског гласа, човека који се вредношћу свога дела и снагом свога утицаја сврстава међу најкрупније ствараоце у нашој култури... Расправљајући о настанку језика, о неразлучној вези појмова и њиховој објективизацији у речи, о језичком стварању и језичком грађењу, Белић је формирао схватање о језичкој динамици, о непрекидној еволуцији изражајне моћи говора, о живом и незалеђеном у 'вечне и непроменљиве норме и калупе”. И даље: „Иако далек по својој стручној формацији од науке којом се Белић бавио, имао сам прилике на путовањима и у заједничком раду на Академијиним задацима да пратим његову многоструку активност и да се дивим ерудицији, гипкости ума који није старио и државничкој способности с којом је Белић, током толиких година, водио нашу највећу научну и уметничку установу, представљао је и персонификовао у свим фазама њеног развоја у том бурном периоду".

Следи опширна студија М. Стевановића Живот и дело Александра Белића. „Своје погледе на језик - пише Стевановић имајући на уму централно Белићево дело - и односе који у њему, међу његовим деловима, међу језичким јединицама постоје, на функције које те јединице у језику врше, и на значења која оне у језичким системима имају, Белић је јасно 
изложио у својим двема објављеним књигама лингвистичких испитивања".

После Стевановићеве студије долази низ прилога о Белићевом лингвистичком учењу, међу којима је Б. Конески (3: 153-158), А. Белић о секундарним вокалима у македонском.

Р. Катичић (3: 173-180), Zabilješke uz sintagmatiku A. Belića, један од највиђенијих хрватских језикословаца, с искреним признањем одаје пошту величини Белићева научног доприноса: „Aleksandar je Belić nedvojbeno izuzetna osoba među jezikoslovcima našega podneblja. On je u Srba razvio lingvistiku do zavidne visine, istakao se na svemu slavenskome jugu kao domaći proučavač domaćega jezika, za čitav je naučni svijet bio visok autoritet u svim pitanjima srpskoga ili hrvatskoga jezika, u svojem je narodu položio temelje znatnoj jezikoslovnoj školi i svojim je utjecajem zračio po svoj Jugoslaviji. Istakao se kao vrstan dijalektolog i zahtjevan povjesnik jezika, prikupio je i sredio golem materijal za njegovu historijsku gramatiku". Тумачећи Белићеве идеје о синтагми, Катичић доспева на терен генеративистичке 'дубинске структуре', јер је за њега латентни садржај речи који се синтагматизацијом, тј. проширењем назива у описну перифрастичну структуру - само експлицирају већ постојећи виртуелни односи које синтагма покреће у сврху промоције актуализованих семантичких комплекса диктираних потребама споразумевања. „Ista latentna mogućnost veličine, sadržana već u sadržaju 'kuća', može se oblikovati tvorbom kućerina, a da se u odnosima dubinske semantike pritom ništa nije promijenilo. Nazire se tako čitav jedan sustav implicitnih semantičkih mogućnosti”.

У крајњој Катичићевој процени Белићева доприноса избија високо мишљење о његовој вредности, о иновативности његових идеја и продорности његова духа, и храбрости да закорачи у нераскрчене домене лингвистичке мисли који ће се тек у постбелићевско доба открити погледу нових истраживача: „Mоže se dakle reći da je Aleksandar Belić u svojoj sintagmatici anticipirao generativnu semantiku i da je sebi suvremen strukturalizam odbijao s pozicija s kojih ga i ona kritizira. Tako se njegovo izdvojeno mišljenje o principima lingvističke teorije danas sve više uklapa u glavne njezine struje. Time se mijenja položaj Belićeve sintagmatike u cjelini novovjekovnoga jezikoslovnog razmišljanja i podjednako se obogaćuju i nauka koju nam je on ostavio i traženja i građenja koja zaokupljuju jezikoslovce našega doba”. Данас се свакако мора утврдити да је и генеративна синтакса и семантика само једна модна епизода коју су потисле друге инстант теорије чији смо сведоци били последњих деценија, и чији смо сведоци данас. Но и без додатка који Катичић подастире под своју оцену, остаје истина да је Белић, најпре, био у приличној мери суздржан у односу на модерне тео- 
рије у лингвистици, као и да је, на крају, прекорачивао у разним правцима границе које су постављале канонизоване теоријске норме свих фаза у развоју лингвистике којима је Белић био сведок, и с којима се суочавао више као са сметњама за развој сопствених мисли него као помоћ у продубљивању својих теоријских уверења.

Св. Марковић (3: 305-309), Став А. Белића у вези с акиентом страних ријечи у Речнику САНУ, извештава о извесним колебањима у акцентовању страних речи, која заправо не значе прекорачење српске акценатске норме.

Р. Коларич (3: 347-358), Govor dveh slovenskih vasi na Madžarskem ob Nežiderskem jezeru, извештава о главним говорним особинама двају дијалекатских пунктова.

Св. Манојловић (3: 359-369), O supstituciji praslavenskih korijenskih *je-, ${ }^{*} c_{c}-,{ }^{*} \check{z} e-u$ čakavštini, расправља о генези и еволуцији чакавског фонолошког система.

\section{3. Јужнословенски филолог}

1. Љ. Стојановић (1860-1930) - таман у години ратног међувремена између балканских и Првог светског рата, - заједно са А. Белићем, оснива часопис 'Јужнословенски филолог, који је ево већ дуже од једног века главна трибина, и може се рећи најснажнија полуга за развој филолошке и лингвистичке науке код Срба, а и код других народа у Југославији и иностранству. Тек што је изашла прва књига, и припремљена друга, избио је разарајући светски рат, који је однео не само ту књигу овог часописа, него и трећину становништва Србије, многе установе, књиге, културна добра - и културне раднике. Године 1918, по свршетку Првог светског рата и стварања Југославије, научни потенцијали знатно многољудније земље постали су далеко већи, па је и потреба за гласилима постала већа. 'Јужнословенски филолог' наставио је са излажењем, наравно са прекидима у току ратова и бурних политичких превирања која су им претходила и за њима следила.

Књига друга 'Јужнословенског филолога' изашла је у две свеске, обележене као 1-2 и 3-4, што је одражавало амбицију уредника А. Белића да знатно прошири број сарадника и обим објављених страница. „'Јужнословенски филолог' - стоји у предговору - и у будућности, као и у прошлости, посвећиваће своју пажњу свему што се тиче јужнословенских језика непосредно или посредно". Проширење на четири свеске није се никада остварило, а и на две је тек после Белићеве смрти остварено. 
2. У заједничком прогласу штампаном у првом броју часописа двојица научника између осталог - наводећи све знатне часописе и зборнике који су у то време излазили у словенском свету и у светској славистици, што „показује без сумње напредак славистике последњих година, и чак полет у извесном правцу” - пишу и следеће: „Према овоме развитку славистике и према потреби, да се и у нас развије у овом правцу живљи рад, којим ће се помоћи, колико се буде могло, и општим испитивањима о словенском језику и проучавању многих тамних страна нашега језика, са покретањем филолошко-лингвистичког повременог списа на нашем језику није се могло више оклевати. Јер иако у нас има академија и научних друштава која објављују радове и из славистике, иако има књижевно-научних часописа у којима се каткада критички пропраћају и новија дела из различних њених области, ипак ми нисмо још имали часописа којему је једини задатак - проучавање нашег језика у вези са осталим јужнословенским језицима и испитивање њихових језичких споменика. Ту празнину, према својој снази и средствима, треба да попуни 'Јужнословенски филолог"'. Једну значајну улогу коју је на себе преузео часопис покретачи помињу на самом крају, а то је факат да ће 'Јужнословенски филолог, „давати на крају сваке године библиографију... онога што је из славистике изашло у току од године дана на нашем језику и што је другде за то време о нашем језику излазило".

3. До вишегодишњег прекида изласка часописа дошло је у Другом светском рату и политичким турбуленцијама по његовом завршетку. Број XVII датиран је 1938-1939, a XVIII тек 1949-1950. У прогласу уредништва између осталог се каже: „Цео културни и научни рад у нашој земљи био је грубо прекинут насилничком окупацијом наше земље и грубим злочинима који су њоме завладали. Тако је и Јужнословенски филолог престао да излази... - Он се сада поново јавља под новим приликама, али после корените реформе наше земље која се јавила као резултат друштвеноекономске револуције извршене одмах после ослобођења. По себи се разуме да ће ново време обележити и нову епоху у нашем раду, иако ће Јужнословенски филолог и даље излазити под старим именом”. Тај 'нови дух' се наравно у науци о језику није никако осетио, него се јављају нови, млади стручњаци који доносе нове идеје и нове истраживачке методе. Отварају се и нови универзитетски и високошколски центри, па се сем београдских, загребачких, љубљанских, у Филологу јављају и професори из Новог Сада, већ раније Скопља, Сарајева итд.

4. Наш је задатак да укратко представимо радове у ЈФ свих аутора изван Београда, а са територије бивших југословенских република и Новог Сада. 
Први рад из те групе аутора, и први латиницом штампан, била је и данас позната студија А. Мусића Značenje perfektivnoga prezenta u negativnim pitanjima u hrvatskom ili srpskom jeziku (JФ I: 27-34). Своју студију М. закључује да у негативним питањима:

„1. Prezent ne znači, da se radnja glagolska ne vrši baš u ono vrijeme, kad se pitanje izriče, nego da se ne vrši ni u jednoj prilici ili da se uopće ne vrši.

2. Budući da radnje buduće stoje do volje subjektove, dobiva... prezent sekundarno značenje spremnosti (ili upravo nespremnosti) subjektove za vršenje radnje glagolske".

А. Стојићевић (JФ I: 91-103), Допуна академиском издағу Марулићеве 'Јудите', бави се допуном тада актуелног издања Јудите на основу ширег текста из 1522. године.

Вл. Ћоровић (ЈФ I: 108-109), Једна народна пјесма забилежена с краја XVIII стољећа, извештава о тексту једне јуначке песме који се чува у Земаљском музеју у Сарајеву.

Вл. Ћоровић (ЈФ I: 130-136), Јован Н. Томић: О сриским народним песмама о одласку Св. Саве у калуђере, даје доста подробан критички приказ.

Фр. Рамовш (JФ II/1-2: 40-49), Razvoj skupin $r+\partial$ in $ә+r$ slovenskem jeziku, расправља о судбини словенских полугласника у словеначком језику: „Splošna slovanska reducirana vokala $\mathrm{b}$ in ь sta in slovenščini najprej sovpala v enotni ə, ki je v slabi poziciji pozneje onemel, v jaki pa se ohranil”. Даља раправа тиче се секвенци из наслова рада.

Х. Барић (ЈФ II/1-2: 50-60), По илирским траговима, прати илирске језичке трагове у хрватској топономастици (Црес - „Контаминацијом ном. Krep са поменутим локалом $K r[e] p e s ̌-t$ даје се извести... облик ${ }^{\star} \operatorname{Kerps}(K r p s)$, на који се своде и слов. С̌res, и хрв. Cres, Cris...”) и у српској ономастици: горун (изводи га из „балканскога корелата хиберско-лигурскога ${ }^{*}$ c/garr' храст').

М. Решетар (JФ II/1-2: 111-114), Дуги сугласници у српскохрв. језику, говори о изговору нпр. најједноставнији, суперревизија и сл.

В. Јагић (JФ II/1-2: 114-115), Нај - нека - немој, кратко се осврће на три наведене речи.

Вл. Ћоровић (JФ II/1-2: 120-126), Завалски рукопис Хиландарског Типи$к а$ и Повальски натпис са Брача - кратко извештава о два наведена текста.

Стј. Ившић (JФ II/1-2: 132-135), S-h. vukodlak dijal. 'lepir' (Semaziologijski prilog iz starog vjerovanja), zaključuje: „Ako uzmemo na um, da su vukodlaci (kao i vjedogonje) po narodnomu vjerovanju bića, koja imaju 
štošta zajedničko s vješticama i morama..., i kad znamo, da se vještice i more pojavljuju i kao lepiri, onda ćemo lako moći dopustiti, da je gdješto moglo nastati vjerovanje, da su vukodlaci, koji se pojavljuju u različitim likovima..., mogu stvoriti u lepira...."

А. Стојићевић (JФ II/1-2: 137-147), Stari pisci hrvatski. Knjiga IX/2, даје критички приказ Гундулићевих дела у издању ЈАЗУ.

Р. Нахтигал (JФ II/1-2: 158-168), Meyer, K. H., Slavische und indogermanische Intonation. Heidelberg 1920, приказује књигу из наслова.

Фр. Илешић (JФ II/3-4: 211-216), Zagrebački primerak Bohorićeve slovenske (slovenačke) gramatike, 1584, даје опис примерка граматике који се чува у загребачкој Свеучилишној библиотеци. Сем основног текста у Граматици су дописани текстови руком читаоца или власника, делом на ћирилици и глагољици.

Фр. Рамовш (JФ II/3-4:227-239), O slovenskem novoakutiranem ò >ó,ó, $\ddot{O},-$, ,V tem članku... hočem le pokazati, da je o v slovenčini v nekih primerih prešel v zelo uzki o (tako na pr. na Gorenjskem in po tem narečju tudi v knjižni slovenščini), ki je v večini narečij zožil celo do skrajne meje, t. j. prešel je v u”.

П. К. Булат (JФ II/3-4: 272-284), Из живота речи, први део рада, посвећен је општим лексиколошким и семазиолошким питањима.

Т. Маретић (ЈФ II/3-4: 296-297), Откле име Светозар, утврђује да је име дошло према роману 'Љубомир у Јелисиуму' Милована Видаковића. Овај је пак име преузео из Рајићеве Историје. „Име је Светозар узео Рајић из Дукљанинова љетописа".

Х. Барић (JФ II/3-4: 297-299), Из балканскога речника, објашњава речи балега („Ја мислим да balega није романска, него предлатинска, балканска реч и то чисто албанскога порекла"); бугарски ватах, ватав (такође албанског порекла).

Фр. Кидрич (JФ II/3-4: 301-308), Trije prispevke k zgodovini slovenskega pismenstva v 16. stol., најпре се пита када је изашла прва словеначка књига, и одговара да је то морало бити 1550.

И. Коштиал (Koštiál) (JФ II/3-4: 308-310), Etimološke bilješke: слов. komaj (Противи се Миклошићеву извођењу из нем. kaum, већ мисли да је ова реч настала према словенском тәкмо); слов. finka, punca.

Х. Барић (JФ II/3-4: 310-311), Стслов. brežda 'носећа', поредећи реч са одговарајућом у литавском, тражи њен индоевропски корен.

П. Скок (JФ II/3-4: 311-318), Из српскохрватске топономастике, објашњава постање речи Гладници („Sasvijem je lako razumljivo, da narod metaforički nazove slabu zemlju gladnom"); Годимирићина (према м. им. Годимир); Градаи („оd grad”), Хумач (и Хум, према хум, тј. hlъmъ); Јагодније 
(„po postanju adjektiv od jagoda”); Јаране („оd jara”); Јошани („oblik sasvim pravilno razvijen iz starijega kao i joha <jelha, jeoha”); Калчина горица („Očito se radi o posjedovnom adjektivu izvedenom od imena znamenite plemićke zadarske porodice (13.-18. stolj.) Calcina"); Камен, Клобук, Кнеж вртал.

Х. Барић (ЈФ II/3-4: 319-323), Јубилеј проф. А. Белића („Ове се године (1921-ве) навршило 20 година од како је А. Белић заузео катедру српског језика и словенске филологије на Београдском Университету, а 25 година од почетка његова научног рада"), Барић дословце цитира пригодни говор самог А. Белића на уприличеној седници Лингвистичког друштва („У земљи у којој овакве свечаности нису у обичају, у којој - бар за живота - никоме не показују особито поштовање, и у којој нико није ни навикао ни да тражи ни да прима какво признање, овакав је акт необичан”).

M. Решетар (JФ III: 1-6), Završetak -u u gen. sing. muških imenica u slovenskom jeziku („Poznata je stvar da srpskohrvatski jezik niti ima niti je kada imao toga završetka, dok ga prilično mnogo ima u slovenskom. Koliko ga tamo ima u sadašnjim dijalektima i u starijim jezičnim spomenicima, to je pokazao Vatroslav Oblak u Jagićevu Archiv-u 11..."), аутор дотадашњим истраживањима додаје да „nalazimo vrlo malo izuzetaka od pravila da u slovenskom jeziku mogu imati u gen. sing. završetak - $u$ samo imenice muškog roda, s jednosložnim nom. sing. i s tvrdom osnovom, koje su u praslav. doba imale silazni akcenat na... korjenitom slogu".

Фр. Фанцев (JФ III: 11-25), O avtorstvu i postanju rječnika „Lexicon..., Zagrabiae 1742. - утврђује ауторство речника.

Н. Мајнарић (JФ III: 35-40), Jedna zanimljiva sintaktička pojava u ravnogorskom narječju („Ravna Gora je veliko i zdravo mjesto u Gorskom kotaru udaljeno od Delnica otprilike 17 kilometara"), расправља заправо о једној семазиолошкој појави: о употреби глагола 'дати' у значењу 'чинити'.

П. К. Булат (JФ III: 41-47), Из живота речи, други део рада, наставак о општим лексиколошким и семазиолошким питањима.

И. Коштиал (Koštiál) (JФ III: 71-77), 1. Stsl. zajęcb, реч доводи у везу са 'зијати'. 2. Iz srpskohrvatske toponomastike: Куктани - различито се бележе у старим документима. Лапчаґь („Mjesto se zvalo Labčanj (Lapčań)... Ime bi bilo prema tome plemenski naziv izveden sufiksom -janinz od imena mjesta ${ }^{\star}$ Labьсь, kao što je pleme Lapčani izvedeno istim sufiksom od Lapьc < Lapac"); Лојиште, мисли да је исто што и ловиште; Митровица; Мјесна имена на -ић („Како је још Цвијић исправно опазио, ова имена стоје у тијесној вези са задружним (фамилијским) насељима, братствима и породицама").

Ђ. Шкарић (ЈФ III: 81-83), Јужнословенска ријечияа ve: „Јужнословенско ve са својим гласовима потпуно одговара староиндискоме va...”. 
Фр. Илешић (JФ III: 83-84), Slovenske 'etimologije': Poljske 'banialuki' - реч тумачи настанком према имену града у Босни; 'Warszawa' - изгледа да је име настало према 'врх'/'врш-'.

Фр. Илешић (JФ III: 192), St. Słoński, Tak zwane perfektum w językach słowiańskih, сажето приказује поменуту књигу, у којој се расправља о преводу грчког перфекта на словенски, при чему у преводу преовлађује аорист. То по аутору значи да грчки и словенски перфекат нису еквивалентни.

П. К. Булат (JФ IV: 95-113), Из живота речи, у наставку својих сту-

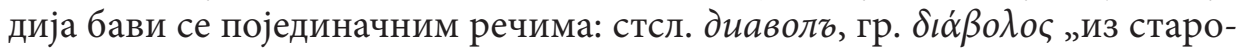
словенскога је црквеним путем дошло до сх. дијаво(a)л, затим од XVIXVII в. и испада и гласи дјаво(a)л, дјаво и напокон ђавао, ђаво".

A. Мусић (JФ IV: 151-165), Prije i poslije, опширно расправља о две прилошке речи, о њихову пореклу и значењу.

И. Коштиал (Kostiál) (JФ IV: 182-184), Етимологичке ситнище, одговара на критички осврт у JФ III, 291 на његов рад из JФ II, 308-310.

Фр. Илешић (JФ IV: 184), Demonstrativno-pronominalni glagoli, врло кратко се осврће на рад Н. Мајнарића JФ III: 35-40, слов. глагол onegati 'чинити нешто неодређено'.

М. Премроу (JФ IV: 187-189), Trojezični rečnik Georgija Vidali, извештава да је „, rimskem arhivu veroplodničnega zbora (s. Congregatio de Propaganda fide)" пронашао молбу Георгија Видалија, свећеника хварскога, да му се одобри штампање тројезичног речника, од којих језика помиње илирски и талијански. Речник није пронашао.

П. Скок (JФ IV: 224-227), Dacoromania I (1920-1), даје приказ првог броја часописа за румунски језик на универзитету у Клужу.

М. Решетар (JФ IV: 245-250), A. Meillet et A. Vaillant, Grammaire de la langue serbo-croate, извештава о изласку из штампе српскохрватске граматике двојице угледних француских слависта. Замера ауторима што су се углавном усредсредили на књижевни језик како се он упражњава у београдском кругу, па нису опазили „да се је у којечему 'класички језик' боље сачувао на западу неголи на истоку”. Иначе, „треба похвалити аутоpe, а у првоме реду сигурно проф. Vaillant-a, што у књизи има којекаквог детаља којег, уколико памтим, нема у досадашњим граматикама нашег језика, па и то доказује с којом је солидном спремом и савјесношћу ова књига израђена".

A. Мусић (ЈФ V: 27-41), Aorist imperfektivnih glagola u srpskohrvatskom jeziku, једна од најзначајнијих у низу Мусићевих расправа о употреби глаголских облика. „Pita se, što takovi aoristi znače, i kako je do njih došlo.” 
a) У вези са првим постављеним питањем Мусић признаје да је најлакши одговор онај који је дао Маретић (Граматика 1899, треће изд. 1963: 616), то јест да је имперф. аорист једнак имперфекту. „Ali kad bi tako bilo, ne bi se razumjelo, zašto se mjesto aorista ne upotrebljava radije imperfekat. Aorist mora imati dakle neko osobito značenje. A to značenje držim da dolazi od značenja, što ga ima aorist, kad mu je glagol perfektivan. Onda aorist znači, da se radnja perfektivnoga glagola u prošlosti izvršila. Pa to značenje valja da ima aorist i onda, kada mu je glagol imperfektivan, samo dakako s tom razlikom, da znači, da se radnja imperfektivnoga glagola u prošlosti izvršila. A to kod imperfektivne radnje znači, da se ne samo vršila, nego i svršila, dakle da je prošla čitava, od početka do svršetka”. Овакво тумачење на корак је близу ономе које дају савремени интерпретатори: да се радња аориста „сагледава у целини свога постојања” (С. Танасић, Синтакса глагола, у књ.: Пипер и др., Синтакса савременога српског језика, Институт за српски језик САНУ, Матица српска: 424 и д.). Мусић за доказ наводи два убедљива примера из 'Светог писма', и њихове грчке и латинске

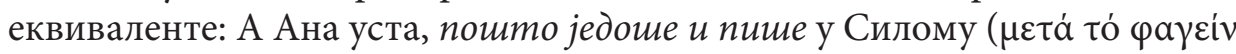
aût

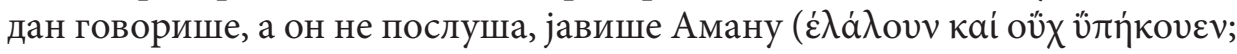
quum dixissent ei quotidie et non auscultasset eis).

Тај корак Мусић је учинио прецизнијим поређењем превода 'Светог писма' са грчким текстом. Утврдио је, наиме, да „se u grčkom tekstu na mjestima, gdje se u srpsko-hrvatskom prijevodu upotrebljava imerfektivan glagol mjesto perfektivnoga, obično nalazi oblik aorista (dakle oblik perfektivnoga glagola)", с тим што је боље било рећи 'перфективни облик', јер грчки не познаје глаголски вид у облику како га имају словенски језици, већ се се по тој дистинкцији одликују глаголски облици.

Мусић скреће пажњу на још једну додатну појединост од значаја за решење проблема који је поставио. То је факат да је аорист обичан не од свих имперфективних глагола, већ углавном од простих имперфектива „n. pr. biti 'percutere', činiti, govoriti, jesti, moliti, piti, plakati, služiti, vladati itd.. Поређењем са префиксираним глаголима, можемо лако утврдити да прости глаголи не знају за исти тип дистинкције перфективност/имперф., о чему је овде сувишно водити расправу. Напоменућемо само толико да српски имперфективни аорист познаје особеност 'перфективности' сличну као код простих перфективних глагола.

б) Али је Мусић упозорио на неке појаве које се тичу исте ствари, а које је приметио код других глаголских облика.

ба) Наиме, по односу према глаголском виду аористу је сличан глаголски прилог прошли: „Ako je glagol perfektivan, taj particip znači, da se 
radnja glagolska ima izvršiti prije radnje glavnoga glagola. Po tom u navedenom primjeru [И постивши се дана четрдесет и ноћи четрдесет, на посљетку огладње]... znači, da je Isus ogladnio, pošto je poštenje izvršio...”.

б6) Сличне прилике Мусић налази и у'евентуалном презенту' (Ја те не могу одријешити од гријеха прво него питам владике), као и у'хисторичком презенту' (Кад му по том Кара-Ђорђије пище, да Турке пошаље у Биоград, одговори му...).

бв) Слично је и у плусквамперфекту са имперфективним основним глаголом (И поједавши опорави се, јер три дана и три ноћи не бјеше ништа јео нити воде пио).

в) Мусић свему, идући за Маретићем, додаје и опаску да постоје глаголи 'имперфективно-перфективни'. „Za neke od njih, koji... služe i kao imperfektivni i kao perfektivni... zabilježio je već Vuk u Rječniku, da su imperfektivni i perfektivni; n. pr. cjelivati, imenovati, krstiti, prstenovati, ručati, silovati, večerati; čuti, vidjeti, kazati... Ali imperfektivno-perfektivno značenje imperfektivni glagoli nemaju sami sobom, nego tek u oblicima, u kojima se pravilno upotrebljavaju samo perfektivni glagoli; tako u aoristu, u participu pret. akt. I, u hist. prezentu itd."

г) Ни Маретић ни Мусић, а ни каснији истраживачи нису обратили нимало пажње на значење перфективности код разних категорија глагола. Утврдили би да ту постоји читава скала, али друкчија од оне коју је Грубор утврдио, и која важи углавном за префиксиране глаголе. Но почев од префиксираних, па преко простих 'тренутних' и даље преко 'двовидских', дакле заправо лексички имперфективних који у датим приликама подлежу видској неутрализацији (ручати, крстити; телефонирати), до оних који само оказионално губе имперфективност (в. горе. писати) - не долази до измене само употребних могућности, већ и значења вида: у последња два случаја 'перфективност' је управо исто што и 'завршеност', одн. 'комплетивност' или 'глобалност', како савремени аспектолози мисле.

д) У вези са другим питањем Мусић мисли следеће: „То su ponajviše prosti glagoli (koji nijesu složeni s prijedlogom)... Aorist imperfektivnih glagola stvorila je dakle nevolja, što nema perfektivnih, koji bi imperfektivnima posve odgovarali, pa se mjesto njih imperfektivni sami meću u aorist.... Ho може бити, и пре ће бити, да је ова особеност свуда где је затечена, заправо остатак старине, чији печат и иначе носе пређашња времена. Да је ово дакле извесна пројекција прастарог индоевропског стања, чији је аорист свакако имао сличну природу као данашњи српски аорист...

Због свега реченог може се слободно рећи да Мусићев рад ни данас није без научне тежине. 
М. Решетар (JФ V: 46-52), Ikavsko-jekavski govor M. Radnića, анализира текст поменутог писца и утврђује у којим је позицијама употребљавао једне, а у којима друге рефлексе јата.

П. К. Булат (JФ V: 130-149, Из живота речи, наставља у ранијим бројевима започету анализу речи, између осталих и са творбеном основом 'ђаво'.

Ђ. Грубор (JФ V: 150-161), Морати, врши анализу семантичког поља наведенога глагола.

Фр. Илешић (JФ V: 162-170), 'Moći i'morati u slovenačkom jeziku, исти тип анализе као горе примењује у односу на две речи словеначког језика.

Ђ. Шкарић (JФ V: 183-184), Српскохрватска ријеч 'таслак', настоји доказати келтско порекло (пореди је са староирским tal).

М. Матковић (ЈФ V: 187-189), Групе tlt u of y источном долетьском говору: „У источном долењском говору... рефлекс је некадашњега -l[вок.] у кратким наглашеним и ненаглашеним слоговима -о-, а у дугим наглашеним слоговима редовно - $u$-, само спорадично затворено -o-: pon : puna, puno...”.

Фр. Илешић (JF V: 189), Malinovac, тим називом залаже се да - према словеначком - назовемо малинов сок.

И. Коштиал (Kostiál) (ЈФ V: 190-192), Shrv. kres, krijes, kris, сматра да је Бернекер у праву кад ову реч изводи од лат. crispus.

Вл. Ћоровић (JФ V: 195-202), исправља и(ли) прецизира неке податке у 'Записима и натписима' Љ. Стојановића: 'Двери у пећи', 'Два шудиковска натписа', 'Натпис из Маркова манастира', 'Натпис са Пречисте у Прилепу', 'Натпис из Ћорулића,' 'Натписи из Пећи'.

М. Тентор (JФ V: 202-214), Prilog Bernekerovu rječniku, бавећи се старијим хрватским дијалектима, аутор је сакупио, и у раду приказао, овелик број речи „kojih nema Berneker, a nema ih A. Rj.”

П. Скок (JФ VI: 65-95), Iz srpsko-hrvatske toponomastike, аутор наставља своја раније започета истраживања о именима места, и бави се речима у којима се јавља лексема 'море' или њена основа, па затим објашњава топониме 'Нови Град,' 'Обровац,' 'Острвица,' 'Ошље', 'Озрен' итд.

Т. Маретић (ЈФ VI: 96-97), Јочи неколико ријечи о глаголу 'морати', додаје неке детаље овде већ нотираној расправи о овим глаголима, па закључује: „Мислим, да ће након овога сватко признати, да се између моћи и морати налази једна семантичка свеза, која не допушта сумњати о постању другога глагола из првог".

A. Мусић (JФ VI: 98-101), Нетопир и лептир: „Ako je vjerojatno, da je netopyrb nastalo od ne-ptyro, još je vjerojatnije da je sh. leptir nastalo od *la-ptyrъ u značenju 'quasi avis (non avis)"'. 
Фр. Рамовш (JФ VI: 135-165), O prvotnih južsl. substitucijah za balk.-lat. $k$, g pred e, $i$, води расправу са П. Скоком (Zur Chronologie der Palatalisierung von c, g, qu, gu vor e, i, y im Balkanlatein, ZfrlPh XLVI), па критички закључyje: „Hotel sem pokazati, da ni niti enega primera, ki bi nas silil v to, da bi za prvotno južno slovanščino suponirali take glasovne skupine in artikulacijske sposobnosti, kakršnih nam naše utrjeno praslovanskega stanja nikakor ne dovoljuje".

M. Храсте (JФ VI: 180-214), Crtice o bruškom dialektu, бележи главне фонетске, морфолошке и синтаксичке црте поменутог говора Брусја на отоку Хвару, и прилаже кратке записе говора.

M. Решетар (JФ VI: 248-251), K. Meyer und A. Stojićević, - Serbokroatisches Lesebuch, Göttingen 1927..., критички се осврће на бележење акцента.

М. Решетар (JФ VI: 252-260), Српски дијалектолошки зборник, књига III, критички се осврће на рад Фр. Илешића о 'Безјацима', М. Павловића „О становништву и говору Јајца”, а о осталима се изражава углавном похвално.

Фр. Илешић (JФ VI: 261-264), објављује кратке приказе пољског часописа 'Prace Filologiczne', као и A. Brückner, Słownik etymologiczny języka polskiego.

А. Кроња (Cronia) (JФ VII: 69-110), Građa o božavskom narječju, бележи главне особине говора Божаве „na sjeveroistočnoj strani Dugog Otoka”: гласови, акценат, облици, синтакса, али не даје текстове у прилогу.

Вj. Главан (JФ VII: 111-159), Kongruencija u jeziku starih čakavskih pisaca, објављује интересантну студију из историјске синтаксе.

Ђ. Грубор (JФ VIII: 13-37), Етимологије, објашњава'Воље, во, ваљање (сукна), вељача'. Може се потврдити и називом '(а)вељӓча' у централној Србији за умршене конопље које остају после брања бољих стабала (в. и РСАНУ: авељ, авељак, авељача).

П. Скок (JФ VIII: 38-64), O slovenskoj palatalizaciji sa romanističkog gledišta, аутор води расправу са Фр. Рамовшем поводом његових погледа објављених у раду ЈФ VI: 135-165. Одбија Рамовшеву тезу о јужнословенском пореклу палатализација, и то са аргументом „da su Sloveni na dalmatinskoj obali sačuvali u premnogo slučajeva i najstariju predslovensku romansku toponomastičku nomenklaturu", која не мора бити захваћена палатализацијама.

M. Решетар (JФ VIII: 83-87), Посиловићев икавско-јекавски говор, додаје неке детаље уз студију у ЈФ V: 46-52 које је забележио код Посиловића. „Овај оглед из Посиловићева говора даје нам дакле нов доказ да је квантитет слога врло важан моменат за развитак старога 'јата' у нашем језику, нарочито што се тиче 'јекавизације' негда чисто икавских говора, 
јер ја и за Посиловићев мјешовити говор узимљем оно исто што сам узео за Раднићев, то јест да је то некад био чисто икавски говор који је почео прелазити у јекавски, и то најприје у дугим слоговима гдје јекавски говор јаче избија. Него тиме нећу да речем да су на тај начин настали сви јекавски говори, - напротив, у томе погледу ја остајем чврсто при томе да се је наш јекавски изговор развио непосредно из старога 'јат', дакле из вокала за који се данас узимље да је при крају 'прасловенске' периоде гласио као ие". Изванредни Решетар је могао претпоставити и друкчију еволуцију јата у икавско-ијекавским говорима, а не искључиво развојем икавизма: могао је узети друкчије стање у дугим, а друкчије у кратким слоговима код самог Раднића и Посиловића, тј. постепену дифтонгизацију у дугим слоговима, а 'икавизацију' у кратким... Насилно прекинута истраживања у западној Србији упућују на такав развој.

П. Скок (JФ VIII: 88-102), Leksikologičke studije, објашњава етимологију речи 'Словенец'.

Фр. Илешић (JФ VIII: 155-159), Jedna konstrukcija sa 'moći' i 'morati', пише о одговарајућим синтаксичким формацијама у словеначком.

М.Храсте(JФ VIII:225-226), Povodom g. M. Maleckoga kritike'Bodulskih Pisama' Pere Ljubića..., кратак похвалан осврт са извесним подацима из говора отока Хвара.

О. Колман (JФ VIII: 269-272), A. Vaillant: Les Piesni razlike de Dominko Zlatarić..., похвалан приказ уз мале напомене о омашкама.

Фр. Илешић (JФ IX: 282-286), Dopuna članku o 'moći' i 'morati' JF VIII..., доноси нову грађу из старијих писаца.

Стј. Ившић (ЈФ Х: 166-170), Glagol 'morati' debeo i imperfekt 'morah' poteram, даје критички прилог расправи о овом глаголу: „Ovim sam člankom, ako ništa više, pokazao da impf. morah 'mogah'... nije izmišljen...”

J. Ившић (ЈФ X: 171-178), 'Jat' u senjskom govoru, извештава о сењским исправама XV в., и утврђује да је замена јата екавско-икавска, као и данашњи сењско-новљански што има прелазну позицију међу југоисточним и северозападним чакавским говорима.

Фр. Илешић (ЈФ X: 179-182), Jedna stilistička primedba, расправа ce тиче словеначког језика и неких синтаксичких германизама.

М. Медић (ЈФ X: 182-185), Да ли 'врбаски' или 'врбашки', поставља питање о исправности 'врбашки', на што му из редакције одговарају да је 'врбашки' према 'Врбашанин', те да је исправно и једно и друго.

M. Решетар (JФ XI: 1-6), Još o 1. sing. imperativa, објављује додатне чињенице уз радове Стј. Ившића и А. Вајана о истим питањима.

О. Колман (JФ XI: 241-273), Milan Rešetar: Djela Marina Držića. Drugo izdanje...Zagreb 1930, прилаже опширан критички приказ. „Друго издање 
дела М. Држића, које је Југославенска академија поверила ванредно спремноме, искусноме и неуморном раднику на том пољу, г. проф. М. Решетару, служи у пуном смислу те речи на част своме приређивачу".

П. Скок (ЈФ XII: 73-146), O bugarskom jeziku u svjetlu balkanistike, врло критички гледа на овај - dvojice nemačkih slavista: Trautmana i Fasmera - „plod... srbofobije”: „Varao bi se ko bi pomislio da je ovaj njemačkim jezikom napisani priručnik onakve prirode kakve su drugi njemački priručnici, da je to miran prikaz činjenica snabdjeven obilnim navodima literature i problema o kojima se još diskutuje u nauci... - U predgovoru veli autor da je pisao ovo djelo kao bugarski rezervni oficir i da je sudjelovao u sva tri posljednja rata redom. Naročito ističe da je ovo povijest jezika bugarskoga naroda, koji je tako često iskušavan i s kojim se veoma često nepravedno postupalo... - Ovako maglovito nagoviještenu političku tendenciju u predgovoru ove historije autor je u toku razlaganja u knjizi sasvim jasno obilježio.... Скок одбија да полемише на тој политичкој линији коју је зацртао бугарски историчар језика Младенов, и у наставку расправе на уму има управо Младеновљеву књигу, jep „kako je djelo Mladenova pisano sa tom pretenzijom da dâ posljednje rezultate do kojih je došla nauka u ispitivanju bugarskoga jezika, red je da se oglasi i balkanistika....”

Скок замера Младенову што фалсификује чињенице из бугарских шовинистичких побуда, што Бугарима проглашава велики део српског народа, што бугарскима сматра говоре на широком простору јужне и источне Србије итд. „Iz ovo nekoliko primera - закључује Скок - jasno izlazi da su u našega historičara bugarskog jezika dvije duše: jedna praktična koja zloupotrebljava lingvistiku u političke i plemenskošovinističke svrhe, i druga - teoriska koja je na sebe navukla naučnu lingvističku masku".

Скок свакако није овим приказом стао на страну Срба против бугарскога народа, нити је за то имао било каквог интереса: он је стао у одбрану науке против покушаја њене злоупотребе у шовинистичке сврхе, на што су се одлучили бугарски и немачки научници у узајамној спрези да би дали одушка мржњи накупљеној у балканским ратовима и светском рату. Ратови свакако не доносе срећу ни победницима ни побеђенима, а не доносе ни просперитет науци ако ова стоји на позицијама одбране лажи против истине. Угледни хрватски научник заслужује свако признање за реч у прилог истини.

Фр. Илешић (JФ XII: 147-186), Iz istorije naših reči, бави се речима 'Univerzitet (sveučilište, vseučilišče, univerza),' 'Kolodvor (železnica, vlak)', a у вези са развојем железничког саобраћаја и ширењем железница из Европе на Балкан.

Ђ. Грубор (JФ XII: 187-198), Значење ријечи 'пособа', човек који је „слободан, самосталан”. 
M. Решетар (JФ XII: 208-210), Što je 'skopos'? истраживање закључује тврдњом „da je... skopos u značenju 'melodija' Vetranoviću, odnosno u Dubrovnik došao... iz terminologije grčke crkve".

M. Решетар (JФ XII: 284-287), P. Skok, Naša pomorska i ribarska terminologija na Jadranu (Spljet) 1933, представља повољан приказ.

М. Решетар (JФ XII: 288-289), Odgovor na odgovor g. prof. Wollman-a, y суштини је неслагање са Волмановим тумачењем Његошева десетерца.

Фр. Илешић (JФ XIII: 151-161), Nešto o Jelsi na Hvaru i o jelšanskom govoru (Topografske i jezičke beleške), даје кратак приказ јелшанског становништва и говора.

Вл. Ћоровић (ЈФ XIII: 162-165), Постанииа бугарског патријарха Јевтимија тисменском архимандриту Никодиму, објављује текст посланице са кратким напоменама.

М. Храсте (JФ XIV: 1-55), Čakavski dijalekat ostrva Hvara, после уводних напомена аутор бележи основне фонетске и морфолошке црте, уз кратке напомене о синтакси и неколико примера хварског говора. У прилогу је карта отока Хвара.

В. Томановић (JФ XIV: 59-141), Акценат у говору села Лепетана (Бока Которска), бележи подробно акценат по категоријама речи и њихових облика. Пре тога, у уводу, излаже основне принципе лепетанског, значи једног од старих црногорских говора: „Поред два силазна акцента (кратког и дугог) у говору села Лепетана постоји само један узлазни, дуги, а и тај је несталан, јер се често место њега изговара обична дужина иза које долази кратки силазни, па се каже сад на́род итд., а сад на̄рöд итд."

А. Клаић (JФ XV: 181-183), O podravskom akcentu i kvantitetu, кратак је приказ акценатских особина.

М. Решетар (JФ XV: 215-232), Ново издаюе свих Његомевих дјела, подробан је у суштини, и углавном повољан приказ Његошевих дела у редакцији Д. Вушовића.

Фр. Илешић (JФ XVI: 99-143), Neke kajkavske (slovenačke i hrvkajkavske) jezičke pojave, naročito u prezimenima, расправља о облицима типа Slomšek-Slomšeka или Slomška, наравно у словеначком језику.

Ф. Стојанов (ЈФ XVI: 158-165), Prilozi poznavanju narodnog govora u Tijesnome (na otoku Murteru), даје основне податке о чакавско-икавском говору поменутог насеља (Tisno).

М. Храсте (JФ XVI: 235-237), I. Jelenović i H. Petris: Antologija nove čakavske lirike, врло је повољан приказ: „Ova će zbirka biti od dragocene vrednosti ne samo za čakavce i sve Jugoslovene nego i za strani svet izvan granica naše domovine". 
J. Вуковић (JФ XVII: 1-113), Говор Пиве и Дробюака, износи најважније црте пивско-дробњачког говора: фонетске, морфолошке и синтаксичке, са исечцима забележеног говора. На крају, у 'додатку', кратко пореди овај говор, практично Вуков родни дијалекат, са Вуковим књижевним језиком, па на крају закључује: „Све ово лепо показује како су и поред све блискости међусобне дробњачки и Вуков тршићки говор имали сваки свој посебан развитак, те ту треба тражити разлике у Вукову језику и данашњем дробњачком говору, уколико се оне не састоје у оним модификацијама којима се Вуков језик одликовао од његовог матерњег тршићког говора". У то време тршићки говор још није био испитан, него ће тек касније Б. Николић показати какве је он природе: до средине XX века он се удаљио од пивско-дробњачке основице и у доброј мери примакао свом шумадијском окружењу.

Стј. Ившић (JФ XVII: 114-129), Neki primjeri asimilacije dentala $t, d$ palatalu l, ń, расправља о облику 'prosuithgluiuuthi' prosvićljujući у Ватиканском хрватском молитвенику (,iz konca 14 ili iz početka 15 vijeka”), -ћљ- се налази и у неким другим писаним споменицима.

Фр. Илешић (JФ XVII: 130-134), Travnik i Dolac u Bosni, извештава да се поред Травничанин говори Травльанин, те поред Дочанин и Долачанин.

Н. Мајнарић (JФ XVII: 135-149), утврђује, поред мешовитих хрватско-словеначких говора у Горском Котару, такође и једну чисто словеначку оазу.

В. Томановић (JФ XVII: 201-217), Мешате речи, сматра мешовитим речима углавном неке необичне лексеме: бупати, бурликати, веднути, гвирити, глимбати, гмеждити итд.

Н. Мајнарић (JФ XVII: 228-233), Dr. August Musić, јесте топао опроштај од преминулог великог научника, уз истицање његових непроцењивих заслуга.

Р. Нахтигал (JФ XVIII: 49-54), O zadnjem poskusu razlage imena češkega naroda, прилог је којим се словеначки стручњак укључује у повремено бурну расправу о народносном имену 'Чех'.

П. Ивић (JФ XVIII: 141-156), при првој појави у великом часопису, тада млади а касније значајан истраживач дијалектолошких простора српских, даје кратак извештај о боравку „у местима Крстуру, Ђали, Волошинову, Фаркаждину, Томашевцу, Боки и Крушчици”. Износи податке са терена, па на крају закључује: „По својој основној структури наш дијалекат несумњиво припада најмлађој штокавској групи. Он има акцентуацију начелно херцеговачку и деклинацију која се креће у правцу херцеговачке". Касније ће се наравно показати оно што је А. Белић већ тада знао: да шумадијско-војвођански говори нису у свему идентични са херцеговачкима, 
те да чине посебну дијалекатску групу (нпр. и Ивићев материјал показује да је дужина на отвореној ултими сасвим ишчезла, или сл.).

П. Скок (ЈФ XVIII: 253-259), E. Petrovici: Graiul Caraşovenilor („govor Krašovana”), Bucureşti 1935), повољно оцењује монографију: „Kako је općenito poznato, Krašovani, na broju oko 7000 duša, stanuju među Rumunjima u brdovitom kraju istočnog Banata, oko $40 \mathrm{~km}$ daleko od jugoslovenske granice. Za ove katolike, koji starinom potječu iz Stare Srbije, po mojem mišljenju iz okoline oko Gnjilana, utvrdio je Ljubomir Miletić da su se doselili ovamo u drugoj polovini XV vijeka, da nijesu Bugari, nego Srbi, koji govore narječjem tipa kosovsko-resavskoga”. Сва каснија домишљања о пореклу Крашована овим су унапред поништена. Једино што остаје необјашњено, јесте њихов католицизам, који су они по свој прилици донели са Косова, где су већ били покатоличени. Узрок сеоба исти је као и у осталим случајевима сеоба Срба са Косова: притисак Албанаца, којем нису подлегали само православни Срби, већ и католици, па делимично очито и православни и католички Албанци. Надимци породица 'Турци' и 'Шиптари', 'Мурићи' или сл. као да једнозначно упућују на то. Познати су случајеви досељавања католика и у централну Србију, и брисања сећања на католичку прошлост.

П. Ивић (JФ XVIII: 318-322), E. Petrovici: Graiul Caraşovenilor („govor Krasovana"), Bucureşti 1935); M. Małecki: Gwary słowiańskie w Banacie rumuńskim, Cracovie 1938. за предмет има такође Петровићеву студију о Крашованима. Критикује аутора за слабо уочаване акценатске дистинкције. „Ове, и неке друге, грешке Петровичи-еве исправља Малецки". Ивић се дуже задржава на проблему порекла Крашована, и износи мишљење да су „дошли са терена оног дијалекта из којег су се доцније развили призренско-тимочки и косовско-ресавски". Та је широка тврдња у складу са оним што Скок прецизније мисли, док су Ивићеве даље експликације о „тимочким” цртама за ово рано доба дијалекатског комплекса непотребне.

И. Поповић (JФ XVIII: 328-330), E. Petrovici: Daco-slava..., после кратког прегледа грађе закључује: „Не може се рећи да је сав овај материјал добро пронађен; има у њему података који показују ауторову необавештеност, има и погрешних закључака; али целокупност материјала показује да ће Петровичи свакако бити у праву: да 'дакословенски' припада источноме јужнословенском типу".

И. Поповић (JФ XVIII: 330-331), E. Petrovici: приказ: I. Kniezsa: Ungarns Völkerschaften im XI Jahrhundert, Dacoromania X, 1943..., дискусија о односу Мађара, Румуна и Словена у поменуто доба. Поповић се тим поводом пита: „даје ли сав овај материјал какве хронолошке податке о словенском 
становништву старе Дакије. Петровичи каже отприлике овако: румунски језик је у оволикој мери могао зајмити од словенскога само у време 'симбиозе', а симбиоза се мора узимати само пре доласка Маџара....”

И. Поповић (ЈФ XVIII: 331-332), E. Petrovici: La population de la Transylvanie au XI-e siècle..., прилог је дискусији о Дакословенима.

И. Поповић (JФ XVIII: 332-333), E. Petrovici: Les Slaves en Grèce et en Dacie..., још један је прилог о старини словенског елемента на Балкану.

М. Ивић (JФ XVIII: 333-335), A. Vaillant - La dépréverbation (Revue des études slaves 19, ...1946), кратак је приказ Вајанове студије.

П. Ивић (JФ XVIII: 336-338), М. Филиповић, Галипольски Срби..., Београд 1946, опет је кратак приказ студије: „Године 1922 пресељена је у Пехчево у Македонији група Срба из Бајрамича (на Галипољском Полуострву у данашњој европској Турској)". Ивић указује на потребу дијалектолошког описа њиховог говора, што ће затим и учинити.

М. Ивић (JФ XVIII: 338-340), R. H. Ružić, The aspects of the verb in serbocroatian..., Berkeley and Los Angeles 1943..., углавном је критички приказ.

И. Поповић (JФ XIX: 159-171), О словенским коренима ${ }^{\star} b q b-u{ }^{*} p Q p-$ и неким юиховим дериватима, врло документована студија о пореклу назива типа 'бубуљ' и сл. те 'пупуљ' и др.

М. Ивић (JФ XIX: 173-212), О предлогу 'по' у српскохрватском језику, одужа је студија о дијахроним и синхроним проблемима употребе наведеног предлога: „Најкрупнију иновацију српскохрватског језика претставља пребацивање свих значења, која је носила веза по + датив, на везу по + локатив".

Вл. Бабић (JФ XIX: 213-224), Употреба историског инфинитива у говорном језику, представља синтаксичку анализу грађе.

Ср. Живковић (JФ XIX: 225-228), Пример хисториског инфинитива у српскохрватском језику, кратак је прилог о истој теми као горе.

В. Томановић (JФ XIX: 245-251), И. Синдик, Комунално уређене Котора од друге половине XII до почетка XV стољећа, скреће заправо пажњу на језичку грађу у приказиваној студији.

П. Ивић (JФ XIX: 252-259), J. Hamm: Štokavština Donje Podravine, Rad $J A Z U$ 257, 1949, углавном повољан приказ, али уз извесне важне напомене. Нпр.: „Mоžda ne bi bilo neumesno postaviti pitanje o eventualnim (razume se ograničenim, vrlo starim, odavno prekinutim i umnogome istrvenim) vezama slavonskog ekavskog sa njegovim istočnim susedom. Zamena jata u Podravini bliža je vojvođanskoj nego kajkavskoj ne samo po tome što uopšte ima ikavizama već po samim tim ikavizmima. Velika većina primera koje Hamm navodi za Podravinu... poznata je i sa teritorije šumadisko-vojvođanskog dijalekta...." 
Св. Марковић (JФ XIX: 312-323), М. Стевановић, Граматика српскохрватског језика за више разреде гимназије, Београд 1951, подробан је и врло афирмативан приказ.

И. Поповић (JФ XIX: 323-334), Лингвистичке и филолочке расправе у Зборнику радова Филозофског факултета Свеучилишта у Загребу (1951), овако започиње свој, иначе повољан, приказ ове едиције: „Зборник радова Филозофског факултета Свеучилишта у Загребу претставља новину у нашем научном животу. Како се у његовом предговору каже, циљ издавача је био да, у складу са великим променама у нашој земљи, окупе у овој књизи разноврсну делатност хрватских научних радника и да тим окупљањем покажу друштвени значај њихових радова. Нарочита заступљеност младих испитивача треба у овом правцу да претставља корак унапред”. Затим аутор приказа наводи студије М. Храсте, Стј. Ившића, Б. Братанића, П. Скока, Ј. Јернеја, Н. Мајнарића, И. Франгеша. Ако упоредимо студије објављене управо у овом и претходном броју ЈФ, постаће јасно зашто углавном изостају у њима нека од водећих, а и нова имена хрватске филологије. Загрепчани се окрећу себи, а напуштају постепено сарадњу у београдским часописима и сл. То су оне опасне тенденције које су лагано али сигурно водиле коначном разлазу, а које су се зачеле већ тада.

П. Ивић (JФ XIX: 334-339), S. Pop, La dialectologie..., Louvain 1950, похвално се изражава о огромној грађи коју је аутор сакупио, али има тим поводом и примедбу на његов 'импресионистички' метод, који „носи у себи велике опасности".

П. Ивић (JФ XIX: 339-343), Slavistična Revija III letnik (Ljubljana 1950), повољан је приказ.

М. Ивић (JФ ХІХ: 344-373), Р. Ф. Микуш, A propos de la Syntagmatique $d u$ professeur A. Belić, овде пише подробан полемички приказ Микушеве негативне критике Белићева учења о синтагми и реченици. Да би изместила из љубљанске атмосфере Микушев покушај дезавуисања Белића на најнекоректнији начин, М. Ивић овако закључује: „Микуш се сам потрудио да се, одмах у предговору своје књиге, огради од љубљанске лингвистичке средине тврдећи да је радио своју критику dans une ambiance linguistique décidément anti-saussurienne, farochement historisante et esthétisante... Тако је и сам потврдио оно што је свима јасно: да озбиљни и савесни љубљански научници немају никакве везе са Микушевим теоријама, критичким укусом и методом. - Зачуђује међутим - додаје М. И. - чињеница да је љубљанска академија издала Микушево дело и тако примила на себе незгодну улогу издавача једне књиге рађене несавесно и незналачки. Познајући иначе солидност издања Љубљанске академије, 
ја се непрестано питам: Како се ово могло догодити?” - Но и поред објаве 'Става Словеначке академије знаности и уметности' - остаје јасно да је овај научни скандал у ствари на истој линији са наравно врло тихим догађајима у Загребу о којима је било речи мало горе. Изјава Академије о 'непажњи' мање је вероватна од претпоставке да је Микушев рад из неких кругова у самој Академији подстицан.

Р. Нахтигал (JФ XX: 81-86), Protobolg. ojim-, бави се етимологијом речи.

Л. Вујовић (ЈФ ХХ: 87-126), Историски пресјек губльена глаголске рекиије у ирногорским говорима, прати по зонама губљење дистинкције локатива и акузатива у народним говорима.

М. Ивић (ЈФ ХХ: 191-211), О проблему падежне системе у вези са савременим схватаюима у лингвистичкој науци, расправља о погледима Л. Хјелмслева и Р. Јакобсона. „Студије Хјелмслева и Јакопсона, које иначе својом појавом несумњиво значе крупан корак унапред у науци о падежима, пате од извесних методских недостатака. Први и основни недостатак јесте потпуна изолација падежне апстракције приликом анализе значења у односу на контекст коме је падеж интегрални део. Други јесте неинтересовање за питање комплексне структуре падежа појединачно узетих". - Ниједан приговор заправо није оправдан. Да би се утврдило опште значење језичке јединице уопште, па и падежног облика, неопходно је посматрати је најпре у парадигматском окружењу, па тек онда - као услов варијације, укључити контекст, који се најлакше испољава у синтагматским условима.

П. Ивић (ЈФ XX: 229-262), Систем значења основних претериталних времена у језику Галипољских Срба, на пажљиво одабраној грађи поменутог говора Ивић прецизно дефинише значење претериталних времена. Посебан значај има његово разумевање имперфекта, о којем Ивић бојажљиво тврди да је код њега „питање односа између релатива и индикатива врло деликатно", допуштајући дакле могућност тумачења овог облика у неким случајевима и као индикативног.

Ј. Вуковић (ЈФ XX: 263-272), Модални облици са имперфектом и перфектом глагола бити + инфинитив главнога глагола, упозорава на постојање периферних форми типа 'Не био га звати', 'бијаше размислити' и сл. - и објашњава њихово значење.

П. Ивић (ЈФ XX: 377-378), Једна белешка Саве Текелије, кратак је осврт на поменуту белешку, и текст.

В. Томановић (ЈФ XX: 405-420), Прилози топономастици јадранских отока, приказује заправо књигу П. Скока Slavenstvo i romanstvo na jadranskim otocima, и осврће се на нека тумачења у њој. 
М. Ивић (ЈФ XX: 423-429) V. Brøndal, Théorie des prépositions... Copenhague 1950, приказује Брендалову књигу: „За Брендала је предлог из синтаксичке перспективе увек или управна реч везана у целину са зависном речју (предлошка функција), или је изолован, директно укопчан у реченицу.... Ове на први поглед сасвим погрешне интерпретације имају ипак врло дубок лингвистички смисао... Слично тумачење у крајњој линији могу добити и везничке речи, и то као управни члан који потчињава и управну и зависну реченицу (Кад падне киша, настаће поплава = Кад (падне киша - настаће...).

М. Ивић (JФ ХХ: 474-478), Z. S. Harris, Methods in structural linguistics... University od Chicago 1951, повољан је приказ Харисове књиге.

П. Ивић (JФ XXI: 97-129), О неким проблемима наше историске дијалектологије, расправља о правцима истраживања који се тек зачињу, и чији је П. Ивић главни заговорник и протагониста. Указује на тешкоће дијалектолога које долазе од општег недостатка писаних споменика, као и од масовних сеоба српског народа, којима су брисане и изнова оцртаване границе међу дијалектима.

М. Ивић (JФ XXI: 165-214), Из проблематике падежних временских конструкција, опширна расправа о падежним конструкцијама за означавање временских односа: „Сви се зависни падежи у словенским језицима могу употребити за обележавање времена; датив само у вези с предлозима, остали и у тој вези и ван ње”.

П. Ивић (JФ XXI: 310-335), И. Поповић, Историја српскохрватског језика, Нови Сад 1955, врло је неповољан приказ. Поповић је „од целе проблематике историје језика” - вели критичар - „обрађивао само једну маргиналну дисциплину као што је питање односа са суседним језицима", па и у томе је аутор направио низ грешака...

М. Ивић (JФ XXII: 141-166), Систем предлошких конструкција у српскохрватском језику, расправља о „три основна питања од посебног, принципског зачаја:

1) имају ли падежи с предлозима своја 'основна значења' и у каквој су она вези с основним значењем исте падежне категорије ван конструкције са предлогом;

2) постоји ли јасан принцип по коме се у оквиру датог језика један одређен тип предлога обавезно појављује или не појављује уз одређени падеж и чиме је то условљено;

3) да ли се може уочити основна развојна тенденција карактеристична за предлошки систем једног конкретног словенског језика поређењем данашњег стања са некадашњим, најстаријим”. 
П. Ивић (JФ XXII: 179-206), Значај тингвистичке географије за упоредно и историско проучаване јужнословенских језика и юихових односа према осталим словенским језицима, низом скица и њиховог објашњења представља сегментацију јужнословенског дијалекатског простора и кретање главних изоглоса.

Ср. Живковић (JФ XXII: 241-264), Ruske riječi u Stullijevu rječniku, бележи русизме.

X. Поленаковић (JФ XXII: 273-288), Доситеј Обрадовиќ кај Македонците, говори о утицају Доситејевом на рад македонских просветитеља и о превођењу његових дела на македонски.

Р. Коларич (ЈФ XXIII: 17-21), Periodizacija razvoja slovenskega jezika, расправа је о историји словеначког језичког комплекса.

Т. Логар (JФ XXIII: 35-37), O izgubi nominalnih končnic v nekaterih primorskih govorih, извештава о губљењу завршних фонема код именица у словеначким дијалектима: „Ker so vokali -i, -u, -e in -o končniški elementi mnogih sklonov slovenske nominalne sklanjatve, je razumljivo, da so zaradi njihove onemitve mnogi skloni v govorih od srednji Soči in Idrijci ostali bez končnic". Овима аутор додаје и приморске говоре.

Б. Конески (JФ XXIII: 39-44), О развитку македонског књижевног језика, износи основне податке о македонском књижевном језику и његовом развоју.

И. Франгеш (JФ XXIII: 45-49), Vrijednosti i granice stilističke kritike, утврђује основна начела стилистичке анализе текста како га он схвата: „Stilistička kritika treba da proučava izraz piščev nošena dubokim osvjedočenjem da se upravo na jeziku najpotpunije očituje i univerzalni i individualni karakter pjesničkog djela, da upravo na takozvanoj 'formi' pisac ostavlja toliko 'otisaka prstiju', da ga je lako identificirati, proniknuti u njegove namjere i naći korijene njegovu stvaranju”. Наравно, ова стилистичка методологија ослоњена је искључиво на интуицију, и не подразумева никакве чвршће аналитичке процедуре да би дошла до резултата. Изванредни духови као Фослер, Кроче, Франгеш и њима равни - немају проблема да се удубе у суштину уметности и без техничких упутстава које би добили од добро програмираних научних пројеката. Али осредњи и слабији аналитичари наилазе на несавладиве тешкоће, и остају увек на крајњој периферији, трудећи се искључиво око форме као такве... Или што је још горе, уместо анализе подмећу својевољно измишљене квази интерпретације.

J. Вуковић (JФ XXIII: 63-68), О проучавағьу језика и стила наших писаца, поред Франгеша (и М. Павловића), и Вуковић је исказао своје погледе на анализу књижевног дела. Он први помиње оно чега се интуитивисти не додирују: „Може се говорити о проучавању језика и стила 
наших писаца у разним оквирима наших тема: са чисто лингвистичких аспеката посебно, и посебно стилистичких, или са лингвистичко-стилистичких. Сваки смер исказује и посебне методе". Као што лингвистика, према томе, располаже изграђеним инструментаријем анализе текста, исто је то преко потребно изградити и у стилистици...

М. Храсте (JФ XXIII: 78-81), Značaj zapadnog štokavskog govora za istoriju i dijalektologiju srpskohrvatskog jezika (Koreferat), аутор заправо исказује своје схватање о теми о којој је реферисао и А. Белић. Обојица аутора истичу да икавски говори садрже већи број старина које су од посебног значаја за разумевање генезе и еволуције штокавског дијалекта.

Фр. Безлај (JФ XXIII: 83-95), Stratigrafija Slovanov v luči onomastike, уз неке примере којима подупире своју тезу о слојевитости ономастичког материјала, аутор изражава и захтев за покретање активности око израде словенског ономастичког атласа.

Фр. Петре (JФ XXIII: 103-111), Problem proučavanja jugoslavenske književnosti XX vijeka, изражава уверење да се југословенске књижевности развијају посебно, свака у свом амбијенту: „Та је književnost, stvaralačka i kritička, nastajala na tri različita jezika, dakle, kod nekoliko naroda. Riječ je o kompleksnim pitanjima, među kojima je ponekad čak i samo djelomično problemska srodnost". У питању су речи заговорника сепаратног бављења сепаратним научним и стручним проблемима.

М. Боршник (JФ XXIII: 113-119), Književna gibanja kot odraz družbenega razvoja slovenskega naroda, изражава уверење да је књижевно стваралаштво у Словенији увек под притиском осећања малог народа да под претњом споља може ишчезнути. Књижевност се у основи мора руководити идејом очувања националног идентитета. „Neglede na to, da dobivajo pobudo tudi od drugod, daje tem gibanjem samosvoj značaj še neko dejstvo, ki se doslej še z nikakršnim razvojem ni dalo blagodejno spremeniti. To dejstvo je naša številčna majhnost. Ta majhnost, ki že tisoč let ogroža naš obstoj, je vzrok, da prti našemu življu, ki se neposredno odmakne od zemlje, hitrejši nacionalni pogin, kakor pri katerem koli večjem, enako žilavem narodu. Od tod neprestana potreba po vračanju $\mathrm{k}$ zemlji in $\mathrm{h}$ kmetu ter po poživljanju kmečke tradicije”. Наравно, ово је само један периферни налог књижевног стваралаштва - чији су стварни задаци далеко изнад усконационалне политике.

J. Бадалић (JФ XXIII: 121-138), Ruski pisci u hrvatskoj kniževnosti - odrazi i utjecaji, износи податке о рецепцији руске књижевности у Хрватској.

Др. Бригљевић (JФ XXIII: 149-155), Nastava književnosti u obaveznoj $s ̌ k o l i$, расправља о плановима, програмима и извођењу наставе у основној и средњој школи. 
Стј. Тежак (JФ XXIII: 157-164), Nastava materinskogjezika u suvremenoj školi, критикује формализам у настави који се своди на учење напамет граматичких правила, и залаже се за модерније приступе настави језика.

Л. Вујовић (JФ XXIII: 235-246), Како се развио екавизам мрковићког говора?, сматра да је екавизам аутохтона црта мрковићког говора.

Р. Коларич (JФ XXIV: 213-224), Slovenska dialektologija, извештај је о дијалектолошким истраживањима словеначких дијалеката (Б. де Куртене, В. А. Богородицки, А. В. Исаченко, У. Јарник, Фр. Закрајшек, К. Штрекељ, В. Облак и др.).

Р. Коларич (JФ XXIV: 359-362), Sloven. in kajk. Purga - purga, од немачког Burg.

\section{4. Закључне напомене}

1. Најпре општи поглед после увида у списе које је уређивао Белић, и оне који су уређивани у његову част. Белић није само централна личност српске науке о језику и науке о српском језику. Он се својим личним деловањем и деловањем часописа који је основао интензивно укључио у веома буран развој филологије и лингвистике у светским размерама. Списак најчувенијих светских имена са почетка нашег прегледа указује на ширину и дубину бављења нашом науком које се одвијало у Београду и око Београда. Драматични историјски догађаји око балканских ратова те Првог и Другог светског рата, условили су прекиде у научном раду балканских и југословенских научних радника, а и још драматичније догађаје у том правцу који су свом силином извршили удар у руској науци, чија су нека најистакнутија имена, као Р. Јакобсон, Н. С. Трубецки и С. Карцевски, прешли у сферу западне лингвистике и појачали њене потенцијале до неслућених висина. Но В. В. Виноградов, Н. С. Бернштајн и др. остају у Совјетском Савезу и успевају одржати ниво деловања и развоја тамошње научне делатности и произвести нове кадрове.

2. Сви се поменути догађаји наравно пројектују на научне прилике у Србији и Београду, а затим и у Југославији. Београд добија знатно појачање у кадровима из Русије, јер ту почињу деловати Стј. Куљбакин, К. Тарановски и други. Рекосмо да су научни потенцијали кадровски нарочито ојачали стварањем Југославије, јер су Загреб и Љубљана постали стални извор списа, па и уређивачких активности за списе издаване у Београду. Политичка збивања и колебања у српско-хрватско-словеначким односима, међутим, нису била без утицаја на ту сарадњу. Наиме, до отприлике 1929, и Шестојануарске диктатуре, која се непријатно про- 
јектује и на језичке прилике и језичку норму (сетимо се 'Правописног упутства'), та сарадња је текла без икаквих сметњи. Чувена имена хрватске науке као. А. Мусић, М. Решетар, Х. Барић, па М. Храсте и др., као и словеначке, Фр. Рамовш, Фр. Илешић и касније Р. Нахтигал, стални су сарадници Београда. После ових догађаја та сарадња из Загреба видно слаби, нарочито после неспоразума Белићевог са Решетаром; а касније, после скандала са 'синтагматиком' Р. Ф. Микуша, словеначки се научници такође повлаче.

3. Клима се мења после Другог светског рата, јер у обновљеном ЈФ стасају нова имена Белићевих директних сарадника какви су П. и М. Ивић и И. Поповић, а донекле и М. Пешикан и др. Тако ЈФ постаје заправо часопис београдског круга, а из њега се издвајају, и групишу око других научних списа, Загрепчани и Љубљанчани. Сепаратизму се отвара широко тло и одлична шанса за деловање, које се касније шири и продубљује у свим доменима. Привремено се југословенски филолошколингвистички корпус окупља поводом „IV конгреса слависта, одржаног у Москви 1-10. X 1958. године” (и првог конгреса Југословенских слависта, септембра 1957. у Београду), чији су реферати објављни у JФ XXIII), али то је био и последњи покушај да се заустави плима сепаратизма на овом пољу. Тако се у XXIV броју, - последњем који смо прегледали, и где је Белић, још увек апострофиран као уредник, стављен у ограду, што значи да тада више није био жив - стигло до ситуација да ЈФ попуњавају углавном београдски стручњаци (Нови Сад је такође добио часописе и такође се почео нагло дистанцирати од Београда), а од ванбеоградских снага нашао се један једини - Словенац Рудолф Коларич, као последњи Мохиканац. Са смрћу А. Белића угасла је привлачна моћ Београда као центра чак и српске лингвистике - нешто вероватно услед погрешне кадровске политике, те с тим у вези и лошег научног подмлађивања - заобилажењем дакле научно најспособнијих, најприљежнијих, и оних који се истичу истраживачком продорношћу и дубином мисли. Нешто, разуме се - и услед општих прилика у земљи.

4. Сада ваља неколико речи рећи и о научном доприносу'небеоградских' истраживања.

a) Тематика прегледаних радова врло је разноврсна, с тим што је у првим временима претежно историјско-компаративна, а касније преовлађују радови из савремених језика, описи дијалеката, морфолошких и синтаксичких црта књижевног језика и сл. Једна значајна чињеница не сме промаћи овом приказу: а то је факат да почевши од првог па до последњег прегледаног броја, најпре сам Белић, а затим сарадници са разних страна, па на крају углавном Белићеви ученици и најближи сарадни- 
ци - помно прате научну продукцију приказима, оценама, критичким напоменама итд.

б) Што се тиче квалитета радова, ми смо покушали да прилоге који су по нашој оцени изнад просека - пропратимо извесним коментаром, као на другој страни укратко и оне који су испод те линије. Поменућемо још једном А. Мусића и Х. Барића, двојицу изванредних познавалаца класичних језика и класичне филологије, и М. Решетара, одличног познаваоца словенске поредбене проблематике, а уз то и равноправних такмаца са Белићем и горе поменутим светским корифејима - чине Олимп зналаца савремених језика и стања у њиховом истраживању. Са такве висине они су успевали продрети у многе тајне језика и изложити своје налазе управо на страницама Белићевих списа. На тај начин они су и себе афирмисали као светске силе у науци о језику, али истовремено и нпр. Јужнословенски филолог као један од водећих светских и словенских часописа у свом домену истраживања. Југословенска славистика и лингвистика, у доба великих историјских драма на тлу Русије и Европе, била је - бар неко време - уз Праг и можда Варшаву, један од највећих научних центара. ЈФ се може мирно сматрати успешним наследником бечког ZfslPh.

5. Но како одмиче време, и како највећи умови одлазе са научне сцене, а нажалост слаби прилив нових снага сличне ширине знања и снаге духа, тако се Олимп полако празни, а слава истраживачких подвига бива ређа појава. И сами научни центри полако тону у устајале воде осредњости, научне установе све су спремније да приме оне који су склонији чувању'мира и реда' него немирним истраживачким подухватима. Не могу проћи мирно бар поред једног прилога у JФ XXIV, 327-357. Ауторка Д. Игњатовић проглашава себе проналазачем, а своје запажање конструкције (Мu?) да идемо кући или сл. у једном шумадијском селу - великим открићем 'незабележеним' у аналима науке („У овом чланку биће речи о једном дијалекатском облику будућег времена, новом и по својој структури и по својој семантици"). Конструкцију без разлога назива футуром, а она има у основи десидеративно значење итд. Сматра је својством само тога локалног говора, а она је честа у говору свих средина, заступљена је у књижевности итд. Ми о томе говоримо само с обзиром на часопис, и на кретање његова угледа од оснивања до Белићеве смрти. 
Белић 1998-2000: А. Белић, Изабрана дела 1-14, Београд: Завод за уџбенике и наставна средства.

Зборник (1) 1921: Зборник филолошких и тингвистичких студија - А. Бетићу, поводом 25. годишғьие юегова научног рада, посвећују негови пријатель и чченищи, Београд: Књижара С. Б. Цвијановића.

Зборник (2) 1937: Зборник тингвистичких и филолочких расправа - А. Бетићу, о четрдесетогодишғиии юегова научног рада, посвећују негови пријатель и иченици, Београд: Млада Србија.

Зборник (3) 1976: Зборник радова о Александру Белићу, ур. М. Стевановић, Београд: Посебна издања САНУ, књ. CDXCVIII, Одељење језика и књижевности, књ. 28.

ЈФ 1913-1960: Јужнословенски филолог. Повремени спис за словенску филологију I-XXIV, издаје А. Белић, Београд.

\section{Radoje Simić}

\section{PARTNERSHIP OF THE PHILOLOGISTS FROM THE OTHER YUGOSLAV CENTRES OUTSIDE BELGRADE IN BELICH'S EDITIONS}

\section{Summary}

Following a survey of the participation of academics from off-Belgrade Yugoslav scholarly centres in proceedings dedicated to A. Belić and in the South Slavic Philologist (I-XXIV), the author supplies a brief assessment of the contributions. The finest and the most numerous came from Zagreb, then from Ljubljana, and other centres submitted a considerably smaller number of lower-quality papers. 